\title{
Buton Cultural Potential in Curriculum Policy Development of Early Childhood Education Unit in Baubau City
}

\author{
Asma Kurniati ${ }^{1)}$, Andi Agustang ${ }^{2)}$ \\ 1) Postgraduate Education Administration Study Program, Universitas Negeri Makassar, Indonesia \\ 2) Universitas Negeri Makassar, Indonesia \\ Corresponding Author: Asma Kurnia,Email: asmakurniati@gmail.com
}

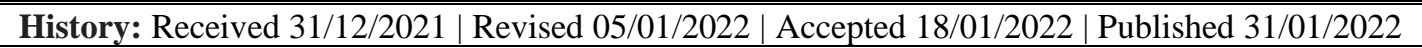

\begin{abstract}
This study aims to determine the potential of Buton culture in developing curriculum policies in the PAUD unit in Baubau City. In this study, the method used is qualitative, located in the city of Baubau. The technique of extracting data is through observation, interviews, and documentation. The study results show that Baubau City is a historical place rich in Buton cultural heritage and has become a tool for harmonization and harmony of diversity that has existed for hundreds of years. Buton culture is not tangible and intangible, so this potential must be preserved, developed, and integrated in a systematic and structured manner, namely through learning activities in the PAUD unit in its development in the PAUD unit, the Buton culture is creatively integrated into appropriate learning themes. . It is hoped that early childhood will have the potential of the Buton cultural character so that the Baubau City Government as a regional policyholder needs to formulate policies as a reference for developing a local curriculum based on Butonnese culture in PAUD units throughout the city of Baubau.
\end{abstract}

Keywords: Buton Culture; Policy of local curriculum; early childhood education

\begin{abstract}
Abstrak. Penelitian ini bertujuan untuk mengetahui potensi budaya Buton dalam pengembangan kebijakan kurikulum di satuan PAUD Kota Baubau. Dalam penelitian ini, metode yang digunakan adalah kualitatif yang lokasinya di kota Baubau. Teknik penggalian data yang dilakukan adalah melalui observasi, wawancara, dan dokumentasi. Hasil penelitian menunjukkan bahwa Kota Baubau adalah tempat bersejarah yang kaya akan warisan budaya Buton dan menjadi alat harmonisasi serta kerukunan keberagaman yang telah ada sejak ratusan tahun yang lalu. Budaya Buton ini tada yang bersifat tangible dan intangible menjadi potensi ini harus dilestarikan, dikembangkan, dan diintegrasikan secara sistematis dan terstruktur yaitu melalui kegiatan pembelajaran di satuan PAUD dalam pengembangannya di satuan PAUD, budaya Buton tersebut diintegrasikan secara kreatif ke dalam teman-tema pembelajaran yang sesuai. Diharapkan anak usia dini kelak memiliki karakter budaya Buton yang petensial tersebut. Sehingga Pemerintah Kota Baubau sebagai pemegang kebijakan daerah perlu untuk menyusun kebijakan sebagai acuan pengembangan kurikulum lokal berbasis budaya Buton di satuan PAUD se kota Baubau.
\end{abstract}

Kata kunci: Budaya Buton; Kebijakan kurikulum lokal; pendidikan anak usia dini 


\section{INTRODUCTION}

Baubau City is located on Buton Island, Southeast Sulawesi Province, and obtained city status in 2001 based on Law no. 13 of 2001. In the past, the city of Baubau was the capital or administrative center of the Sultanate of Buton, to be precise in Wolio, known as the Buton Palace.

The population of Baubau can be characterized as a heterogeneous society, consisting of a mixture of various ethnic groups, namely, Wolio, Cia-CIA, Pacana, Bugis, Javanese, Karingkaring (Bali), Muna, Chinese, Toraja, and others. They also still adhere to the values of their original culture. However, these different ethnicities still communicate in Indonesian as a formal language, such as in schools/education units. Meanwhile, the Wolio regional language is still used to communicate in society.

As the former administrative center of the Sultanate of Buton, Baubau city has various cultural heritages of the Sultanate of Buton as a proud form of the past civilization. Such as Fort Keraton Buton or Fort Wolio, which is declared the world's largest fort. In addition, there are also various cultural values of Butonese that are still alive in the heterogeneous city of Baubau.

Such as the cultural value of Buton Sara Pataanguna, which has long been the life philosophy of the Buton people (Putra, 2018). And this is a buffer for the various tribes/ethnicities in the city of Baubau to live in harmony and respect each other. In ethnic, social structures other than Wolio, these cultural values can be a tool for maintaining harmony because these values have a basis that follows the cultural values of the various ethnic origins. This continues to be the people's personality in Baubau City from generation to generation. And there are many other forms of Bhutonese culture.

Buton cultural values can become an umbrella for the cultural diversity of various ethnicities in Baubau City. (Tahara, 2019) argues that Butonese cultural values can be integrated into the school or formal curriculum. The types of formal education in Early Childhood Education (PAUD) are Kindergarten (TK) and Raudatul Athfal (RA) (Primanisa \& Jf, 2020).

In 2020, there are 172 Kindergartens (TK) and 29 Raudatul Athfal (RA) formal Early Childhood Education (PAUD) units in Baubau City. There are 342 kindergarten teachers and 152 RA teachers. The number of students in kindergarten is 3,235 , and in RA, there are 1,715 students (BPS Baubau City, 2021). Thus, in Baubau City, there are 101 PAUD units with 494 teachers and 4,950 students/early children.

Then, the Regulation of the Minister of Education and Culture Number 146 of 2014 concerning the 2013 PAUD Curriculum imposes several principles considered in the development of the PAUD curriculum (Fadlillah, 2017). Among them, namely, the 
PAUD curriculum should be contextualized

(Hadiansah \& Rabiussani, 2019), in this case considering regional characteristics, school conditions, and student needs. In addition, the curriculum is designed so that all development programs become the basis for the development of the child's personality as a whole (Wijaya, 2017). In addition, the curriculum is built taking into account the socio-cultural characteristics of the local community, with an emphasis on cultural preservation. In this situation, the curriculum must cover various possible demands, problems, and profiles of the local area so that early childhood can understand, respect, and love the local culture. Thus, Buton culture can be integrated into the PAUD curriculum as a cultural feature of the local community so that early childhood learns contextually.

Based on the results of the initial data mining, it was found that there was concern from the community who thought that the children's knowledge of Buton's cultural values was getting less and less known to the children or was only known to me at certain times. In addition, it was also found that the local content curriculum at the Early Childhood Education level in Baubau City does not yet exist, so it has an impact on the difficulty of preparing the PAUD unit level curriculum in integrating/based on Buton culture as local culture as stated in Regulation of the minister of cultural education Number
146 of 2014 concerning Curriculum 2013 PAUD.

Several studies related to Butonese culture that can be used as learning materials in early childhood education have been carried out, such as the research conducted by (Kurniati, 2017) about Butonese folklore as literacy material in early childhood education. The research was also conducted by (Kurniati et al. 2020) about the local wisdom of woven sarongs and traditional Buton clothes as learning materials in PAUD. (Kurniati et al, 2020) also researched the development of early childhood children's emotional, social, and emotional abilities through traditional Buton games. Research conducted by (Jeti et al. 2020) on implementing the Buton BhinciBhinciki Kuli philosophy in early childhood. Research conducted by (Tahara, 2021) on the cultural values of Sara Pataanguna as the heritage of Butonese ancestors that contribute to socio-ethical norms.

However, these studies only focus on some of Buton's cultural values used as learning materials in PAUD. There has been no research that has focused on studying the potential of Buton culture in the development of PAUD curriculum policies. So that this research is directed towards the cultural potential of Buton in the development of curriculum policies for the Early Childhood Education unit as a new value. Where this study can have implications for the formulation of PAUD unit level curriculum 
policies that formally incorporate Butonnese cultural values into PAUD learning.

\section{RESEARCH METHODS}

The research method used was qualitative research, which Sought to explore in detail and in-depth in obtaining sufficient data and focus on studying the potential of Butonese culture in developing curriculum policies for early childhood education units. This research method to study a natural condition, where researchers were directly involved in providing meaning or interpretation based on facts, symptoms, or reality. Related to this research, the researcher was directly involved and provided an interpretation of a fact or symptom about Butonese culture that could develop curriculum policies for early childhood education units. This research was conducted in Baubau City.

In the first stage of the research, the researcher made preparations by conducting a preliminary study, searching written power data or literature studies, and completing and making other data as comparisons such as regional profiles and local people's lives. An in-depth study of the literature focuses on the analysis of policies and the results of previous research. Furthermore, the researchers developed research aids in interview guidelines, observations, and documentation.

The second stage was that the researcher extracts data/information with an interview, observation, and documentation techniques related to the research focus. Observations were made through observations on the tangible culture of Buton. In-depth interviews focused on obtaining intangible cultural data of Butonese and strengthening other information for Butonese culturalists, heads of PAUD units, PAUD academics, and others. Documentation was carried out to record the data obtained in documents, photos, and recordings that were useful as supports to strengthen the findings. The results of observations and interviews were made in field notes and contained conclusions and interpretations.

The third stage was data processing, which includes: (1) data reduction, namely the process of selecting, focusing, simplifying, and transforming the raw data that emerges from field notes; (2) data transformation, namely the process of transforming rough data that emerged from field notes by reducing some of them. The reduced data was data that did not support the focus of this research. (2) Presentation of data, namely the presentation of reduced data or information in the form of pictures or tables, to describe as a whole and easy drawing conclusions from the data collection. 


\section{DISCUSSION}

Policies related to Early Childhood Education Curriculum

The operating principle or method adopted to govern decision making is referred to as a policy (Desrinelti et al., 2021). Moreover, policies can be seen as guiding principles that guide behavior towards a particular goal, problem or activity (Safitri et al., 2021). So policies can be characterized as provisions that provide principles that guide the methods used to achieve certain goals (Mushlih, 2018). With regard to early childhood education, policy can be stated as a concept that defines general goals and how to implement activities or take necessary actions to achieve goals within the scope of early childhood education.

The government provides support for local culture-based curricula through national policies (Suharto \& Solihati, 2020). There are several national policies that have been implemented and can provide reinforcement for the development or issuance of local culture-based curriculum policies by local governments, which can be seen in Table 1 below:

Table 1. National Policy on Curriculum in Early Childhood Education

\begin{tabular}{|l|l|l|}
\hline No & \multicolumn{1}{|c|}{$\begin{array}{c}\text { Kebijakan } \\
\text { Nasional }\end{array}$} & \multicolumn{1}{c|}{ Muatan } \\
\hline 1. & $\begin{array}{l}\text { Law Number 20 } \\
\text { of 2003 } \\
\text { concerning the } \\
\text { National } \\
\text { Education } \\
\text { System }\end{array}$ & $\begin{array}{l}\text { Government } \\
\text { determines } \\
\text { national policies } \\
\text { and national } \\
\text { standards }\end{array}$ \\
\hline
\end{tabular}

\begin{tabular}{|c|c|c|}
\hline & & $\begin{array}{l}\text { education to } \\
\text { ensure the quality } \\
\text { of national } \\
\text { education. } \\
\text { Reference } \\
\text { curriculum } \\
\text { development } \\
\text { based on the } \\
\text { uniqueness of } \\
\text { regional potential. }\end{array}$ \\
\hline 2. & $\begin{array}{l}\text { Presidential } \\
\text { Regulation of the } \\
\text { Republic of } \\
\text { Indonesia } \\
\text { Number } 60 \text { of } \\
2013 \text { concerning } \\
\text { Integrative } \\
\text { Holistic Early } \\
\text { Childhood } \\
\text { Development }\end{array}$ & $\begin{array}{l}\text { The development } \\
\text { of Holistic } \\
\text { Integrative AUD } \\
\text { is carried out in an } \\
\text { integrated and } \\
\text { harmonious } \\
\text { manner between } \\
\text { related service } \\
\text { institutions, } \\
\text { according to } \\
\text { regional } \\
\text { conditions, based } \\
\text { on a constructive } \\
\text { culture. }\end{array}$ \\
\hline 3. & $\begin{array}{lr}\text { Minister } & \text { of } \\
\text { Education } & \text { and } \\
\text { Culture } \\
\text { Regulation } \\
\text { Number } \\
\text { concerning } & 146 \\
\text { Curriculum for } \\
\text { Early Childhood } \\
\text { Education }\end{array}$ & $\begin{array}{lr}\text { Contains } & \\
\text { guidelines } & \text { for } \\
\text { curriculum } \\
\text { development at } \\
\text { the education unit } \\
\text { level to assist } \\
\text { educators in } \\
\text { developing } \\
\text { contextual } \\
\text { operational } \\
\text { curricula. }\end{array}$ \\
\hline 4. & $\begin{array}{l}\text { Law of the } \\
\text { Republic of } \\
\text { Indonesia } \\
\text { Number } 23 \text { of } \\
2014 \text { concerning } \\
\text { Regional } \\
\text { Government. }\end{array}$ & $\begin{array}{l}\text { There is a division } \\
\text { of education- } \\
\text { related affairs } \\
\text { between the } \\
\text { central, } \\
\text { provincial, and } \\
\text { local } \\
\text { governments. }\end{array}$ \\
\hline 5. & $\begin{array}{l}\text { Government } \\
\text { Regulation } \\
\text { Number } 57 \text { of } \\
2021 \text { concerning } \\
\text { National } \\
\text { Education } \\
\text { Standards }\end{array}$ & $\begin{array}{l}\text { Efforts to improve } \\
\text { the quality of } \\
\text { education in } \\
\text { accordance with } \\
\text { the demands of } \\
\text { changes in local, } \\
\text { national and } \\
\text { global life. }\end{array}$ \\
\hline
\end{tabular}




\begin{tabular}{|l|lr|l|}
\hline 6. & Decree of the & \multicolumn{2}{|l|}{ The PPA and IPV } \\
Minister of & instruments for \\
Education and & accreditation of \\
Culture of the & PAUD units \\
& Republic rof of & contain \\
& Indonesia & assessment points \\
Number & regarding the \\
$71 /$ P/2021 & reference to the \\
concerning & PAUD unit level \\
PAUD and PNF. & curriculum, a \\
Accreditation & mixture of \\
Tools & national and local. \\
\hline
\end{tabular}

Based on Table 1, it is known that there are national policies whose contents are related to culture-based curriculum in Early Childhood Education. Law Number 20 of 2003 concerning the National Education System in Article 36 paragraph (1) Curriculum development is carried out concerning national education standards to achieve national education goals. Article 36 paragraph (2) states that curriculum development is carried out in various ways to allow adjustment of educational programs in PAUD units to the conditions and characteristics of the region's potential. Then in article 50, paragraph (2), it is stated that the government determines national policies and national education standards to ensure the quality of national education. The implication is the existence of national policies and National Education Standards.

Minister of Education and Culture Regulation Number 146 of 2014 concerning the 2013 PAUD curriculum contains a basic curriculum framework based on an educational philosophy rooted in the nation's culture. Children are the inheritors of the nation's creative culture. They were developed based on the diverse culture of the Indonesian nation with the principle of Bhineka Tunggal Ika. The competencies embedded in this curriculum will guide early childhood to become heirs of the nation's culture who are creative and care about the problems of society and the nation.

School is a means of sharing experiences and forming children's character (Gitananda \& Trisdyani, 2020). Indonesia is a multicultural country in the unity of Bhineka Tunggal Ika as a strong national character to this day. The 2013 PAUD curriculum frames culture so that children become proud, which is reflected in their personal, social, and national lives. The sociological foundation of this curriculum emphasizes that Indonesian society is diverse, and the PAUD unit represents this diverse society. This Permendikbud also contains guidelines for curriculum development at the education unit level to assist educators in developing contextual operational curricula. The implication is that there is a basic curriculum framework and structure of the PAUD curriculum, learning guidelines, KTSP development guidelines, and educator guidebooks containing contextual learning operational guidelines in PAUD units.

Presidential Regulation of the Republic of Indonesia Number 60 of 2013 concerning Integrative Holistic Early Childhood Development states that one of the specific objectives of developing Integrative Holistic 
Early Childhood is the implementation of integrated and harmonious early childhood services among related service institutions, according to regional conditions; and the realization of the commitment of all related elements. In addition, Article 3 states that one of the references in the holistic and integrative early childhood development is a constructive culture-based principle. One of the strategies carried out is to internalize religious and cultural values, as stated in Article 4. So that it has implications for the internalization of constructive religious and cultural values in Integrative Holistic PAUD, this is supported by (Kasmiati, 2021) opinion that learning planning in PAUD needs to be designed to include the values of multiculturalism.

The Law of the Republic of Indonesia Number 23 of 2014 concerning Regional Government explains a division of affairs related to the education sector between the central, provincial, and regional governments. There is a division of affairs, one of which is the local government's determination of the local content curriculum, early childhood education, where the determination of the local content of PAUD curriculum is the business of the local government.

Government Regulation Number 57 of 2021 concerning National Education Standards contains efforts to improve the quality of education following the demands for changes in local, national, and global life. National Education Standards are used to reference curriculum development and education administration to realize national education goals. Material development must be contextual following PAUD environmental conditions, local culture, institutional support capacity, and social life around PAUD. The results of (Susanti et al, 2021) support that learning activities in PAUD can be innovated from various natural materials as a form of local wisdom. (Kurniati, 2019) also added that children would know the real environment when children play in their surroundings. The child will know how he behaves, and this will be a provision for his life readiness when socializing later.

The themes and sub-themes of the scope of the PAUD curriculum material are arranged according to the characteristics, needs, stages of child development, and local culture. This shows that children's local culture is essential in preparing the PAUD curriculum. So that curriculum development in PAUD units must follow the region's potential, students, and the school environment.

Decree of the Minister of Education and Culture of the Republic of Indonesia Number 71/P/2021 concerning PAUD and PNF Accreditation Tools, where in the Accreditation Prerequisite Assessment (PPA) and Visitation Assessment Instruments (IPV) there are assessment items regarding the PAUD unit level curriculum reference, one of which is a mixture of national and local which will have value if it fulfills one of the elements 
such as the PAUD unit having a reference document for a mixed national and local curriculum.

b. Buton's Cultural Potential for Early Childhood Education

Buton or Wolio is a kingdom or sultanate that used to exist on the island of Buton. (Tahara, 2019) states that Buton has a government system in the form of a kingdom built by immigrants from Johor whose primary goal is to introduce Islam. With the introduction of Islamic ideas in the 16th century, the kingdom's position was changed to a sultanate that lasted for approximately 400 years and was completed in the 20th century (in 1960) with the death of Sultan Laode Muhammad Falihi as the last sultan. Buton Island, Muna Island, and surrounding islands such as Kabaena Island and Wakatobi Islands, as well as the Poleang and Rumbia areas on the Southeast Sulawesi Peninsula, Selayar Island, which is now part of the province of South Sulawesi, and the Maluku Islands, are all part of the territory of the Sultanate of Buton. Buton's government center is located in the Baubau City area, in Wolio, and is also known as the Buton Palace.

Based on the study results, it was found that the PAUD unit in Baubau city had not introduced Buton culture through integration into the local content curriculum at the PAUD unit level. The activity in Baubau city requires children to wear traditional Butonnese clothes or a touch of Butonese in competition activities. This is in line with Hayati's opinion (2021) that, in general, PAUD units introduce culture to children only through children's participation in several activities, such as children's day carnivals.

Many Butonese cultures can be integrated into the PAUD unit curriculum. The Butonese culture in Baubau City, which can be used as learning material in Early Childhood Education, can be seen in Table 2 below.

Table 2. Buton's Culture in Baubau City as Potential Learning Materials in Early Childhood Education.

\begin{tabular}{|c|c|c|}
\hline No & $\begin{array}{l}\text { Type of } \\
\text { Culture }\end{array}$ & Name of Culture \\
\hline A. & Tangible & $\begin{array}{ll}\text { 1. } & \text { Forts: Wolio Fort, } \\
\text { Sorawolio Fort, } \\
\text { Baadia Fort, Fort } \\
\text { 2. } \begin{array}{l}\text { Palace : Kamali } \\
\text { Baadia Palace, }\end{array} \\
\text { Scientific Palace, } \\
\text { Malige } \\
\text { 3osque: Masigi } \\
\text { Ogena, Quba } \\
\text { Masjid Mosque } \\
\text { 4. House: Kamali } \\
\text { Kara, Kamali Bata } \\
\text { 5. Stone: Popaua } \\
\text { Stone, Gandangi } \\
\text { Stone } \\
\text { 6. Flagpole : } \\
\text { Kasulana Tombi } \\
\text { 7. Cave: Arupalaka } \\
\text { Cave }\end{array}$ \\
\hline B. & Intangible & $\begin{array}{ll}\text { 1. } & \text { Traditional } \\
\text { Ceremonies: } \\
\text { Posuo, Posipo, } \\
\text { Alana Bulua, } \\
\text { Dole-Dole, } \\
\text { Tandaki } \\
\text { 2. Ethnic diversity: } \\
\text { Wolio, Cia-cia, } \\
\text { Pancana, Bugis, } \\
\text { Javanese, }\end{array}$ \\
\hline
\end{tabular}




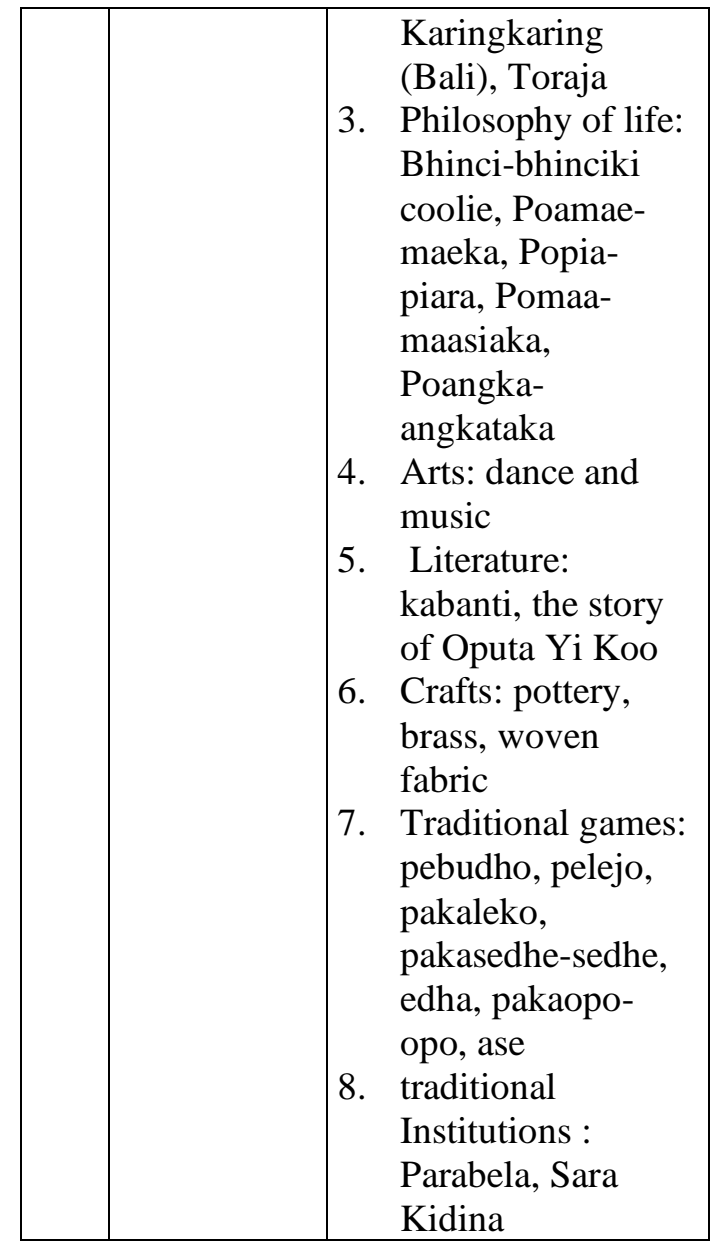

Based on Table 2, it is known that the Butonese culture in Baubau city consists of tangible and intangible cultures. Baubau City, as an area of the former Sultanate of Buton, has a lot of cultural heritage that is hundreds of years old which can be used as a potential for regional development. Not only in the field of tourism but will have an impact on the field of education such as early childhood education. (Hastuti \& Hidayat, 2014) argue that there are two types of cultural heritage: tangible and intangible.

The theme chosen in early childhood learning is the closest theme to the child's life environment in relation to early childhood education. So that culture can be a stimulus so that children gain experience, knowledge and skills. Buton culture is a tool of minds with various variations. For example, one of Buton's tangible cultures is Wolio Fort.

The Buton culture of Wolio Fort can be used as an inspiration for children when playing with blocks on the theme of my environment. Children can arrange blocks that are shaped like Wolio Fort. In addition, the teacher can also combine the Butonese heroic stories, such as the story of Oputa Yi Koo as an archipelago hero from Buton.

One of Buton's cultures that is intangible is the philosophy of life. (Taharu \& Mustaqim 2020) argue that the philosophy of Butonese culture, the value of Koiimani-KosabaraKoikiri, can be integrated into learning. In addition, the research results of (Husniah et al. 2020) supports it. Namely, traditional Buton games can improve students' prosocial abilities.

Butonnese culture has not been integrated into the PAUD unit level curriculum because no specific policy regulates this. (Kurniati et al. 2020) argue that early childhood learning materials can be innovated by integrating the local wisdom of an area. These studies and conditions indicate that policies related to local curriculum development that utilize Butonnese culture are essential, so local governments must formulate these policies. 
Buton culture-based local PAUD curriculum is needed to integrate and foster enthusiasm for Butonese traditional values and culture. The integration of Butonese culture into the PAUD curriculum will have implications for the preservation and development of Butonese culture and as a basis for teaching social, cultural, and educational values in early childhood. This is supported by (Wulansari, 2017) opinion that the development of a curriculum with local wisdom can be carried out in all PAUD institutions in Indonesia to prevent the extinction of local culture. Then children will know and love the natural, social, cultural and spiritual environment in their area. As well as strengthening early childhood character education (Amil et al., 2019).

Thus, the Butonese culture is a potential that can be integrated into the PAUD unit curriculum. Its application makes children recognize their environment, play an active role in society, have character, and become heirs of the nation's creative culture.

\section{CONCLUSION}

Baubau City is an area full of Buton's cultural heritage, a source of pride. This potential must be maintained, developed, and its values integrated into the personality of the nation's next-generation starting at an early age. For this reason, a policy by the local government is needed that can be obeyed and becomes a guide or guide for PAUD units in
Baubau City so that they can integrate Butonese culture into the PAUD unit curriculum.

The author would like to thank all those who have assisted in completing this research, especially the lecturers in charge of courses at the Education Administration Study Program, Makassar State University. This article still needs improvement. The researcher hopes that this research can provide significant benefits for the broader community of enthusiasts, researchers, observers and practitioners of children's education at this age.

\section{REFERENCES}

[1] Amil, A. J., Wulandari, R., \& Farahiba, A. S. (2019). Sakera Seelok Dara "Sekolah Anak Pesisir Madura Sesuai Kearifan Lokal Budaya Madura" Sebagai Penguatan Pendidikan Non Formal Masyarakat Pesisir Pantai Madura. Jurnal Ilmiah Pangabdhi, 5(2), 131-136. https://doi.org/10.21107/pangabdhi.v5i2.611 5

[2] Agustang, A., Suardi, I. A. M., Mutiara, I. A., \& Ramlan, H. (2020). SOCIAL PRENEUR DALAM PENANGGULANGAN KEMISKINAN DI KECAMATAN BISSAPPU KABUPATEN BANTAENG. Martabe: Jurnal Pengabdian Kepada Masyarakat, 3(2), 331-342.

[3] Agustang, A. (2020). Symbolic Violence towards Students in the Context of the Existence of the Stereotypical Frames of Lecturers and Students in the Higher Education System in Indonesia. PalArch's Journal of Archaeology of Egypt/Egyptology, 17(2), 249-258.

[4] Agustang, A. (2020). The Symbolic Violence Towards Private School Students Through The Frame Stereotype In Bantaeng District 
Of Indonesia. Prosiding ICoISSE, 1(1), 578588.

[5] BPS Kota Baubau. (2021). Kota Baubau Dalam Angka 2021.

[6] Desrinelti, D., Afifah, M., \& Gistituati, N. (2021). Kebijakan publik: konsep pelaksanaan. JRTI (Jurnal Riset Tindakan Indonesia), $6(1), \quad 83$. https://doi.org/10.29210/3003906000

[7] Fadlillah, M. (2017). Model kurikulum pendidikan multikultural di taman kanakkanak. Jurnal Pembangunan Pendidikan: Fondasi Dan Aplikasi, 5(1), 42. https://doi.org/10.21831/jppfa.v5i1.13286

[8] Gitananda, W. A. S., \& Trisdyani, N. L. P. (2020). Pendidikan Karakter Berbasis Educare Di Paud Sai Prema Kumara Denpasar. Dharmasmrti: Jurnal Ilmu Agama Dan Kebudayaan, 20(2), 142-153. https://doi.org/10.32795/ds.v20i2.1038

[9] Hadiansah, D., \& Rabiussani, R. (2019). Pembelajaran Muatan Lokal Bahasa Sunda Dalam Perspektif Kurikulum 2013 PAUD. Jurnal Pendidikan Pembelajaran, 1(2), 76$83 . \quad$ http://ejournal.uicmunbar.ac.id/index.php/jp3m/article/download /192/99

[10] Hastuti, K., \& Hidayat, E. Y. (2014). Purwarupa Tangible Cultural Heritage Kategori Cagar Budaya tak Bergerak Berbasis Database Multimedia. Seminar Nasional Teknologi Informasi Dan Multimedia 2014, 1.14.1-1.14.5. http://ojs.amikom.ac.id/index.php/semnastek nomedia/article/view/294/274

[11] Hayati, M. (2021). Pengembangan Program Pembelajaran Tematik Berbasis Nilai-Nilai Keislaman untuk TK/RA. Jurnal Obsesi: Jurnal Pendidikan Anak Usia Dini, 6(1), 457-472.

https://doi.org/10.31004/obsesi.v6i1.938

[12] Husniah, W. O., Ulfa, M., Ode, L., Susanto, H., Bimbingan, P., \& Keguruan, F. (2020). BIMBINGAN KELOMPOK MELALUI PERMAINAN TRADISIONAL BUTON UNTUK MENINGKATKAN PROSOSIAL SISWA. 3(3), 253-261.
[13] Kasmiati, K. (2021). Perencanaan Pembelajaran Nilai Multikultural Anak Usia Dini. Jurnal Obsesi : Jurnal Pendidikan Anak Usia Dini, 6(1), 492-504. https://doi.org/10.31004/obsesi.v6i1.1274

[14] Kurniati, A. (2019). Skills Developed by Early Childhood From Local Authority Of OME Indigenous Environment. August, 6-8.

[15] Kurniati, A., Kudus, I., Marwah, M., \& Hartati, H. (2020). Pembelajaran Kearifan Lokal Pakaian Adat Suku Buton bagi Anak Usia Dini. Jurnal Obsesi : Jurnal Pendidikan Anak Usia Dini, 5(2), 1101-1112. https://doi.org/10.31004/obsesi.v5i2.737

[16] Mushlih. (2018). Analisis Kebijakan PAUD. Penerbit Mangku Bumi.

[17] Primanisa, R., \& Jf, N. Z. (2020). Tindak Lanjut Hasil Asesmen Terhadap Pelaksanaan Pembelajaran Anak Usia Dini di Taman Kanak-Kanak (TK). (JAPRA) Jurnal Pendidikan Raudhatul Athfal (JAPRA), 3(1), $1-14$.

https://doi.org/10.15575/japra.v3i1.8100

[18] Putra, A. (2018). CITRA PEREMPUAN DALAM CERITA RAKYAT WAINDHOINDHODHIYU PADA MASYARAKAT WAKATOBI. 7(1), 20-29.

[19] Safitri, U., Nuarizal, A., \& Gistituati, N. (2021). Urgensi analisis kebijakan. JRTI (Jurnal Riset Tindakan Indonesia), 6(1), 72. https://doi.org/10.29210/3003818000

[20] Suharto, P. P., \& Solihati, T. A. (2020). Analisis Kebutuhan Siswa SD Terhadap Bahan Ajar Bahasa Inggris Berbasis Budaya Lokal Sunda. Metodik Didaktik: Jurnal Pendidikan Ke-SD-An, 15(2), 100-109. https://doi.org/10.17509/md.v15i2.21679

[21] Susanti, S. M., Henny, \& Marwah. (2021). Inovasi Pembelajaran Anak Usia Dini Berbasis Kearifan Lokal melalui kegiatan Eco print di masa pandemic covid-19. Jurnal Obsesi : Jurnal Pendidikan Anak Usia Dini, 5(2), 1987-1996. https://doi.org/10.31004/obsesi.v5i2.594

[22] Tahara, T. (2019). Rencana Induk Pembangunan Kebudayaan Kota Baubau. Kainawa: Jurnal Pembangunan \& Budaya, 1(1), 17-29. 
[23] Taharu, F. I., \& Mustaqim, F. (2020). Integrasi Nilai Koiimani-Kosabara-Kofikiri (K3) pada Pembelajaran di Kota Baubau. Kainawa: Jurnal Pembangunan \& Budaya, 2(1), 21-34. https://doi.org/10.46891/kainawa.2.2020.1934

[24] Wijaya, E. M. (2017). Pembelajaran Bahasa Berbasis Kurikulum 2013 di PAUD Asparaga Malang. CENDEKIA, 11(2), 249-262.

[25] Wulansari, B. Y. (2017). Pelestarian Seni Budaya Dan Permainan Tradisional Melalui Tema Kearifan Lokal Dalam Kurikulum Pendidikan Anak Usia Dini. Jurnal INDRIA (Jurnal Ilmiah Pendidikan Prasekolah Dan Sekolah Awal), 2(1), 1-11. https://doi.org/10.24269/jin.v2n1.2017.pp111 